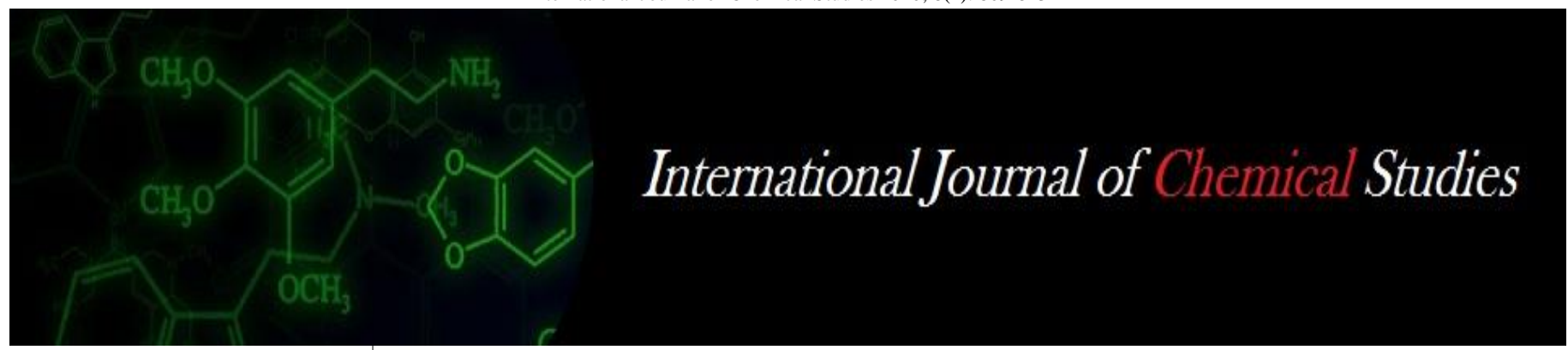

P-ISSN: 2349-8528

E-ISSN: 2321-4902

IJCS 2020; 8(1): 809-813

(C) 2020 IJCS

Received: 11-11-2019

Accepted: 15-12-2019

\section{RM Beldar}

M. Tech Student, Dept. of Soil and Water Cons. Engg., Dr.

Panjabrao Deshmukh Krishi

Vidyapeeth, Akola,

Maharashtra, India

\section{MU Kale}

Assistant Prof., Dept. of

Irrigation and Drainage Engg.,

Dr. Panjabrao Deshmukh Krishi

Vidyapeeth, Akola,

Maharashtra, India

\section{GU Satpute}

Head Dept., Dept. of Soil and

Water Cons. Engg., Dr.

Panjabrao Deshmukh Krishi

Vidyapeeth, Akola,

Maharashtra, India

SM Talye

Ex. Head, Dept. of Soil and

Water Cons. Engg., Dr.

Panjabrao Deshmukh Krishi

Vidyapeeth, Akola,

Maharashtra, India
Corresponding Author: RM Beldar

M. Tech Student, Dept. of Soil and Water Cons. Engg., Dr. Panjabrao Deshmukh Krishi

Vidyapeeth, Akola,

Maharashtra, India

\section{Trends of rainfall and rainy days at Sindewahi station in Vidarbha of Maharashtra}

\author{
RM Beldar, MU Kale, GU Satpute and SM Talye
}

DOI: https://doi.org/10.22271/chemi.2020.v8.i11.8365

\begin{abstract}
Changes in climate over the Indian region would have significant impact on agricultural production, water resources management and overall economy of the country. This study focuses on Rainfall variation and detecting trends in the annual, monthly, seasonal and weekly rainfall and rainy days for Sindewahi station in Chandrapur District (eastern part) in Vidarbha Region of Maharashtra State. The analysis of rainfall variation was done by using statistical parametric test and trend analysis was done by using Mann-Kendall and Sen's slope test. The results revealed that no trend in annual and seasonal rainfall and rainy days whereas rising trend of rainfall observed in September months at 90 per cent confidence level. In rainfall and rainy days SMW 22 and SMW 30, 38 showed decreasing and increasing trend respectively. There are rising rates of rainfall and rainy days in other months and decreasing trend in some other months obtained at non-significant condition by these statistical tests suggesting overall insignificant changes in the area. The decreasing trend in rainfall, rainy days creating the moisture deficiency during crop growing period which ultimately is losing the productivity in rainfed agriculture. To mitigate the adverse effect of uncertainty of rainfall, it is proposed to adopt the location specific in situ soil and moisture conservation practices before and after commencement of the rains and to harvest the excess runoff into farm ponds and recycled for providing protective irrigation for sustainable rainfed agriculture.
\end{abstract}

Keywords: Rainfall, rainy days, trend, sindewahi station, mann-kendall test, sen's slope

\section{Introduction}

Rainfall is a key input in management of agriculture and irrigation projects and any change in this variable can influence on sustainable management of water resources, agriculture and ecosystems. Water resource has become a prime concern for any development and planning including food production, flood control and effective water resource management. Studies have demonstrated that global surface warming is occurring at a rate of $0.74 \pm 0.18{ }^{\circ} \mathrm{C}$ over 1906-2005 (IPCC, 2007) ${ }^{[4]}$. Impact of climate change in future is quite severe as given by IPCC reports which signify that there will be reduction in the freshwater availability because of climate change. This has also been revealed that by the middle of 21 st century, decrease in annual average runoff and availability of water will project up to $10-30 \%$ (IPCC, 2007) ${ }^{[4]}$.

Study of different time series data have proved that trend is either decreasing or increasing, both in case of temperature and rainfall. Human interference is also leading to climate change with changing land use from the impact of agricultural and irrigation practices (Kalnay and Cai, 2003) ${ }^{[5]}$.

Climate change is a long term process. It has raised as most alarming issue for the whole world. Therefore, quantification of climatic changes has become necessary. Trend analysis is a method to determine the spatial variation and temporal changes for different parameters associated to climate. Mann-Kendall Test has been used to find any trend of rainfall, temperature and evapotranspiration (both monthly and annual) which has shown some significance in case of rainfall and temperature.

The prime objective of this study is to analyse the annual rainfall variation and trend of rainfall and rainy days in Sindewahi station of Vidarbha region.

\section{Material and Methods}

Study area

The Sindewahi research station is selected as study area a representative station in Chandrapur district (eastern part) of Vidarbha region of Maharashtra under the jurisdiction of Dr. 
Panjabrao Deshmukh Krishi Vidyapeeth, Akola. Geographically, it is situated at $20^{\circ} 17^{\prime} \mathrm{N}$ latitude and $79^{\circ} 39^{\prime}$ Elongitude and at altitude of $214 \mathrm{~m}$ above MSL. The normal annual rainfall of station was $1305 \mathrm{~mm}$ in 64 rainy days.

\section{Data collection}

The required daily rainfall data at Sindewahi station was obtained from AICRP on Agrometeorology, Dr. PDKV, Akola. The acquired data were in the form of daily rainfall for47 years (1970-2016). This daily rainfall data was converted to the annual, seasonal, monthly and weekly rainfall. The rainy days were determined from rainfall data for further use.

\section{Trend analysis}

Trend analysis was statistically examined in two phases i.e., initially the presence of a monotonic increasing or decreasing trend was tested using the non-parametric Mann-Kendall test (Mann, 1945; Kendall, 1975) ${ }^{[7,6]}$. Then the rate of change was estimated with the help of Sen's slope test (Sen, 1968) ${ }^{[8]}$. The slope of the trend indicates the rate and direction of change (Helsel and Hirsch 2002; Drapela and Drapelova 2011) $)^{[3,1]}$.

\section{Statistical test for variability trend and analysis Coefficient of variation}

The coefficient of variation (CV) is a statistical measure of how the individual data points vary about the mean value. A Greater value of $\mathrm{CV}$ is the indicator of larger spatial variability, and vice versa. In this study, annual rainfall variability has been analyzed for Sindewahi station of 47 years CV.

\section{Mann-kendall test (Non-parametric)}

Let $\mathrm{x} 1, \mathrm{x} 2, \ldots \mathrm{xn}$ represent $\mathrm{n}$ data points where $\mathrm{xj}$ represents the data point at time $\mathrm{j}$ and $\mathrm{xk}$ represent the data point at time $\mathrm{k}$ and $\mathrm{N}$ is the number of data points then the Mann-Kendall statistic ( $\mathrm{S}$ ) is given by the following formula;

$$
\begin{aligned}
& S=\sum_{k=1}^{N-1} \sum_{k=i+1}^{N} \operatorname{sgn}\left(x_{j}-x_{k}\right) \\
& \operatorname{sgn}\left(x_{j}-x_{k}\right)=\left\{\begin{array}{ccc}
+1 & \text { if }\left(x_{j}-x_{k}\right)>0 \\
0 & \text { if }\left(x_{j}-x_{k}\right)=0 \\
-1 & \text { if } \left.\left(x_{j}-x_{k}\right)<0\right)
\end{array}\right\}
\end{aligned}
$$

For $\mathrm{n} \geq 10$, the statistic $\mathrm{S}$ was approximately normally distributed with the mean i.e. $\mathrm{E}(\mathrm{S})=0$ (Drapela and Drapelova 2011; Gilbert RO 1987) ${ }^{[1,2]}$ and variance as follows.

$\operatorname{VAR}(S)=\frac{n(n-1)(2 n+5)-\sum_{p=1}^{q} t_{p}\left(t_{p}-1\right)\left(2 t_{p}+5\right)}{18}$

Where,

$q=$ Number of tied groups,

$\mathrm{t} p=$ Number of data values in the pth group.
The standard test statistic $\mathrm{Z}$ computed as follows

$$
Z=\left\{\begin{array}{cc}
\frac{(S-1)}{\sqrt{\operatorname{Var}(S)}} & \text { when } S>0 \\
0 & \text { when } S=0 \\
\frac{(S-1)}{\sqrt{\operatorname{Var}(S)}} & \text { when } S<0
\end{array}\right\}
$$

$\mathrm{Z}$ here follows a standard normal distribution. The presence of a statistically significant trend was evaluated using the $Z$ value. A positive and negative value of $Z$ indicates an upward trend and downward trend respectively. In the present study, confidence level of 99, 95 and $90 \%$ signify the positive or negative trends determined by the test statistic. At the $99 \%$ significance level, the null hypothesis of no trend is rejected if $|\mathrm{Z}|>2.575$; at the $95 \%$ significance level, the null hypothesis of no trend is rejected if $|\mathrm{Z}|>1.96$; and at the $90 \%$ significance level, the null hypothesis of no trend is rejected if $|Z|>1.645$.

\section{Sen's slope test}

To estimate the true slope of an existing trend (as change per year) the Sen's nonparametric method is used. If a linear trend is present in a time series, then the true slope (change per unit time) was estimated by using a simple nonparametric procedure developed by Sen $(1968)^{[8]}$.The magnitude of trend is predicted by the Sen's slope test.

This means that linear model $f(t)$ can be described $f(t)=Q t+$ B ------(5)

Where,

$\mathrm{Q}_{\mathrm{t}}$ - Slope, B - Constant

The slope $T_{i}$ of all data pairs can be computed by,

$$
Q_{t}=\frac{x_{j}-x_{k}}{j-k} \text { For } \mathrm{i}=1,2,3, \ldots, \mathrm{N}
$$

Where $\mathrm{x}_{\mathrm{j}}$ and $\mathrm{x}_{\mathrm{k}}$ are considered as data values at time $\mathrm{j}$ and $\mathrm{k}$ $(\mathrm{j}>\mathrm{k})$ correspondingly. The median of these $\mathrm{N}$ values of $\mathrm{Ti}$ is represented as Sen's estimator of slope which is given as:

$$
Q_{t}=\left\{\begin{array}{cc}
T_{\frac{N+1}{2}} & \text { if } N \text { is odd } \\
\frac{1}{2}\left[T_{\frac{N}{2}}+T_{\frac{N+2}{2}}\right] & \text { if } N \text { is even }
\end{array}\right\}
$$

Sen's estimator is computed as Qmed $=\mathrm{T}_{(\mathrm{N}+1) / 2}$ if $\mathrm{N}$ appears odd, and it is considered as Qmed $=\left[\mathrm{T}_{\mathrm{N} / 2}+\mathrm{T}_{(\mathrm{N}+2) / 2}\right] / 2$ if $\mathrm{N}$ appears even. At the end, Qmed is computed by a two sided test at $100(1-\alpha) \%$ confidence interval and then a true slope can be obtained by the non-parametric test. Positive value of $\mathrm{Q}_{t}$ indicates an upward or increasing trend and a negative value of $\mathrm{Q}_{t}$ gives a downward or decreasing trend in the time series. Makesens Excel template used for the statistical analyses of rainfall and rainy days time series. (Salmi et al. 2000) ${ }^{[9]}$. 


\section{Results and Discussion}

Trend analysis of Sindewahi station has been done in the present study with 47 years of precipitation data from 1970 to 2016. Mann-Kendall and Sen's slope test has been used for the determination of the trend (Upadhye et al. $)^{[10]}$.

\section{Annual variation and trends of rainfall and rainy days}

Annual rainfall variations at Sindewahi station of 47 years are presented in Fig.1. It represents the annual rainfall for 47 years with maximum rainfall occurrence in the years 1975 with the total rainfall of $2380 \mathrm{~mm}$ approximately and minimum rainfall has occurred in the year 1996 with the total of around $767.6 \mathrm{~mm}$. Average rainfall for these 47 years is $1284.2 \mathrm{~mm}$ in 60 rainy days. The standard deviation was observed at Sindewahi station $323.7 \mathrm{~mm}$ at 25.21 per cent coefficient of variation.

Annual rainfall and rainy days trend of Sindewahi station in over the 47 years didn't exhibit any statistical significant trend at the significance level of 90 per cent, 95 per cent and 99 per cent.

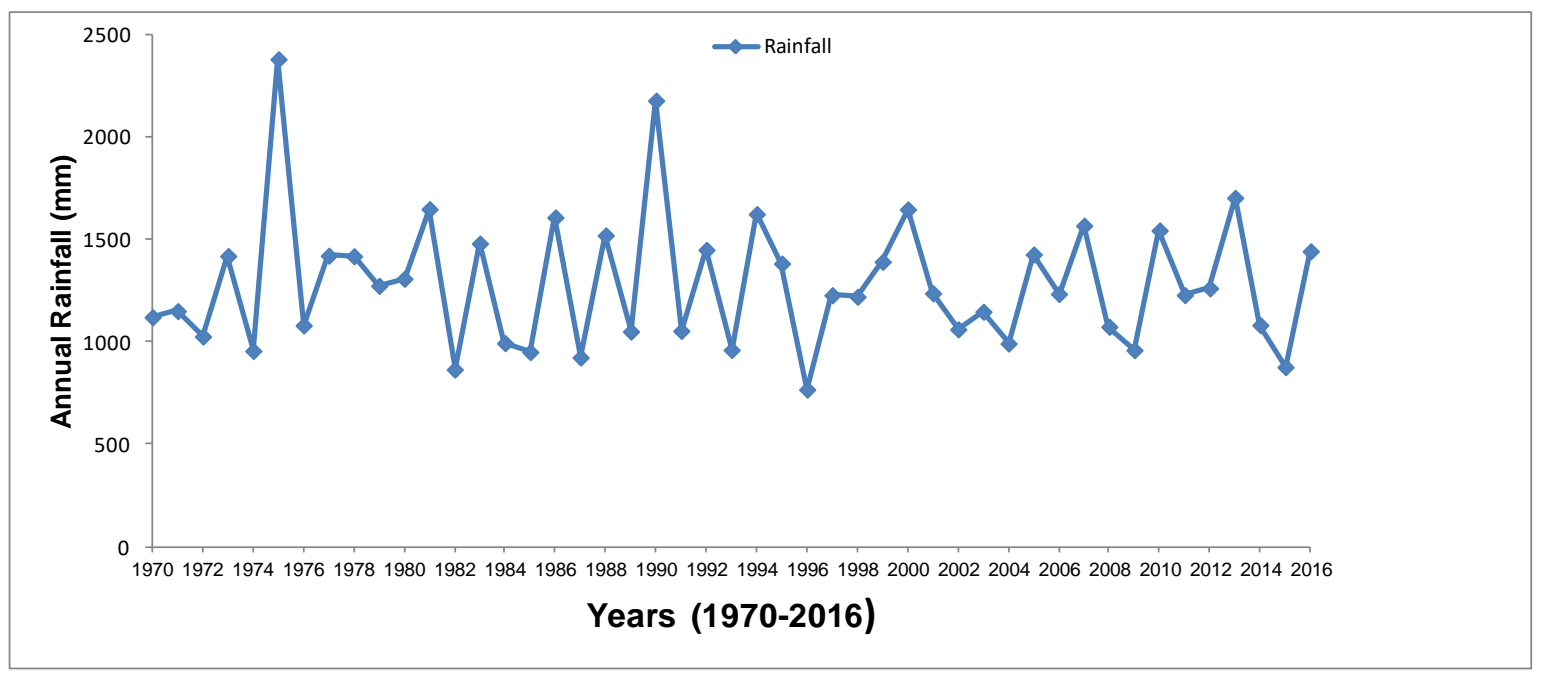

Fig 1: Annual Rainfall variations at Sindewahi station of 47 years

\section{Seasonal trends of rainfall and rainy days}

Mann- Kendall and Sen's slope test results revealed that seasonal rainfall and rainy days at Sindewahi station over the 47 years period in kharif, rabi and summer season did not show any statistical significant trend at significance level.

\section{Monthly trends of rainfall and rainy days}

In the non parametric Mann-Kendall test, trend of rainfall and rainy days for 47 years from January to December has-been calculated for each month individually together with the Sen's magnitude of slope $\left(\mathrm{Q}_{\mathrm{t}}\right)$ as presented in Fig. 2 \& 3.

From Fig 2, it is observed that the monthly rainfall at Sindewahi station during the months of January, February, March, April, May, June, July, August, October, November and December didn't exhibit any significant trend at considered levels of significance, but only September month observed statistical significant trend. The trend was significant increasing $(Z=1.89)$ of about $\left(Q_{t}=2.27 \mathrm{~mm} /\right.$ year $)$ at 90 per cent confidence level. The $Z$ statistics shows nature of monthly rainfall trends at Sindewahi station during September month was significantly increasing.

In the Mann-Kendall test the $\mathrm{Z}$ statistics that reveals the trends of monthly rainfall seri es for 47 years for individual 12 months from January to December were as $0.88,-0.58,1.25,-0.13,-0.72,-0.72,0.51,-0.84,1.89,-0.17$, 0.17 and -1.26 , respectively. For March, July and September, trend was rising while $\mathrm{Z}$ value was showing negative trend in January, February, April, May, June, August, October, November and December.

Thus, $\mathrm{Z}$ values for two months show a positive trend and nine months it shows negative trend representing almost nonsignificant condition but remaining one month i.e. September representing positive trend in the significant condition as shown in Fig. 2
Sen's slope $\left(\mathrm{Q}_{\mathrm{t}}\right)$ for rainfall for 47 years was calculated for 12 months and depicted in Fig 2. It shows rising slope magnitude from March and July and falling slope for May to June and August although a non- significant one but only one month of September shows significant rising $\left(\mathrm{Q}_{\mathrm{t}}=2.27 \mathrm{~mm} /\right.$ year)trend at 90 per cent confidence level. The remaining month did not shows rising or falling trend (slope) due to magnitude of trends was $0.00 \mathrm{~mm} /$ year

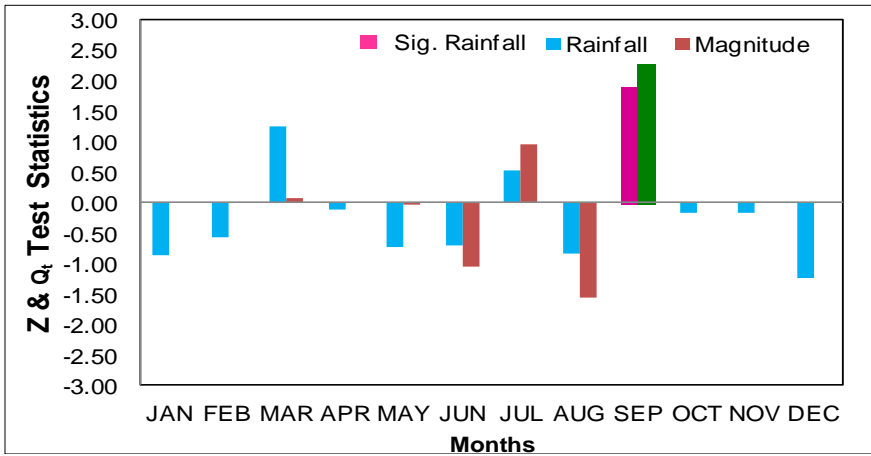

Fig 2: Mann Kendall and Sen's slope trend statistics of monthly rainfall at Sindewahi station

The statistical trends for monthly rainy days at Sindewahi station for the period 1970 -2016 (47 years) for January to December did not show any significant trend at considered levels of significance (Fig.3) In the Mann-Kendall test the $\mathrm{Z}$ statistics that reveals the trends of monthly rainy days for 46 years for March, July and September trend was rising while Z value was showing negative trend in January, February, April, May, June, August, October, November and December. Thus, $\mathrm{Z}$ values for three months shows a positive trend and nine months it shows negative trend representing almost nonsignificant condition as shown in Fig.3. 


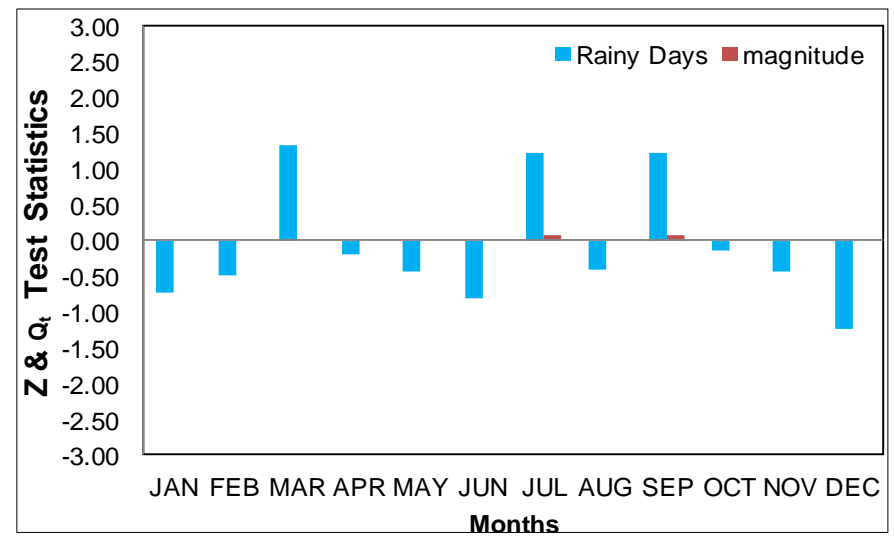

Fig 3: Mann Kendall and Sen's slope trend statistics of monthly rainy days at Sindewahi station

\section{Weekly trends of rainfall and rainy days}

According to IMD standard meteorological weeks are considered for weekly trends analysis of rainfall and rainy days. Weekly rainfall and rainy days trends at Sindewahi station was analysed using Mann- Kendall test and Sen's slope as shown in Fig. $4 \& 5$.

Weekly rainfall during the weeks $21^{\text {st }}, 23^{\text {rd }}-29^{\text {th }}, 31^{\text {st }}-37^{\text {th }}$, and $39^{\text {th }}-45^{\text {th }}$ did not exhibit statistical significant trends at considered significance levels, respectively. At Sindewahi station, weekly rainfall during $22^{\text {nd }}, 30^{\text {th }}$ and $38^{\text {th }}$ weeks shows statistically significant trend at significance levels. (Fig.4)

From Fig. 4 rainfall trend at Sindewahi station was SMW $22^{\text {nd }}$ (28 May to 3 June), showed significant decreasing trend $(\mathrm{Z}=$ $2.18)$ of about $\left(\mathrm{Q}_{\mathrm{t}}=0.00 \mathrm{~mm} / \mathrm{year}\right)$ at 95 per cent confidence level and SMW 30 ${ }^{\text {th }}$ (23 to 29 July) and $38^{\text {th }}$ (17 to 23 September) observed significant increasing $(\mathrm{Z}=1.68)$ of about $\left(\mathrm{Q}_{\mathrm{t}}=0.92 \mathrm{~mm} / \mathrm{year}\right)$ and $(\mathrm{Z}=1.82)$ of about $\left(\mathrm{Q}_{\mathrm{t}}=0.29\right.$ $\mathrm{mm} /$ year) at 90 per cent confidence level respectively.

Trend of weekly rainy days at Sindewahi station during $21^{\text {st }}$, $23^{\text {rd }}-29^{\text {th }}, 31^{\text {st }}-37^{\text {th }}$, and $39^{\text {th }}-45^{\text {th }}$ SMW did not show statistical significant trend at confidence levels. From Fig.5, weekly rainy days during the weeks $22^{\text {nd }}, 30^{\text {th }}$ and $38^{\text {th }}$ shows statistically significant trend at significance level.

From Fig. 5 rainy days trend at Sindewahi station SMW $22^{\text {nd }}$ (28 May to 3 June), showed significant decreasing trend $(\mathrm{Z}=$ 1.77) of about $\left(\mathrm{Q}_{\mathrm{t}}=0.00 \mathrm{~mm} /\right.$ year $)$ at 90 per cent confidence level and SMW 30 $0^{\text {th }}$ (23 to 29 July)and $38^{\text {th }}$ (17 to 23 September) observed significant increasing $(Z=1.95)$ of about $\left(\mathrm{Q}_{\mathrm{t}}=0.04 \mathrm{~mm} / \mathrm{year}\right)$ at 90 per cent confidence level and $(\mathrm{Z}=$ 1.69) of about $\left(\mathrm{Q}_{\mathrm{t}}=0.00 \mathrm{~mm} / \mathrm{year}\right)$ at 90 per cent confidence level.

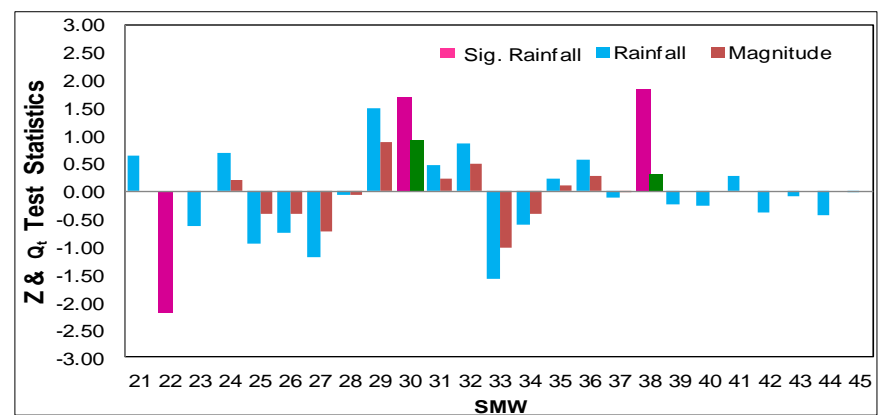

Fig 4: Mann Kendall and Sen's slope trend statistics of weekly rainfall at Sindewahistation

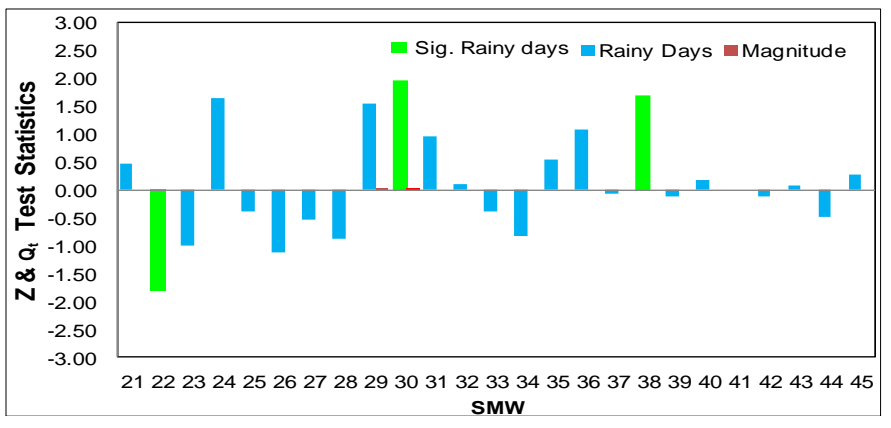

Fig 5: Mann Kendall and Sen's slope trend statistics of weekly rainy days at Sindewahi station

\section{Conclusion}

The present study analyzed the rainfall data for 47 years from 1970 to 2016 of a Sindewahi station for the determination of the trend of precipitation. The area is rural and thus represents more of agricultural land and cultivation zones. The $\mathrm{Z}$ value of MK Test represents both positive and negative trend in the area although not much significant. The results shows no trend in annual and seasonal rainfall and rainy days whereas individually months of September showing significant positive trend at 90 per cent confidence level.

In rainfall and rainy days SMW 22 and SMW 30, 38 showed decreasing and increasing trend respectively. Rainfall varies in different months for different years which are evident in the graphs. Sen's Slope is also indicating increasing and decreasing magnitude of slope in correspondence with the MK Test values. Therefore it can be concluded that there is evidence of some change in the trend of precipitation of the region in these 47 years in different months. Further, study of the area may reveal other aspects which will be helpful into mitigate the adverse effect of uncertainty of rainfall, it is proposed to adopt the location specific in situ soil and moisture conservation practices before and after commencement of the rains and to harvest the excess runoff into farm ponds and recycled for providing protective irrigation for sustainable rainfed agriculture. It helps in agricultural planning and management of water resources.

\section{References}

1. Drapela K, Drapelova I. Application of Mann-Kendall test and the Sen's slope estimates for trend detection in deposition data from BilyKriz (Beskydy Mts., the Czech Republic) 1997-2010. Beskydy. 2011; 4(2):133-146.

2. Gilbert RO. Statistical methods for environmental pollution monitoring. Van Nostrand Reinhold, New York, 1987, 204-223.

3. Helsel DR, Hirsch RM. Statistical methods in water resources. Techniques of Water-Resources Investigations of the United States Geological Survey, Hydrologic Analysis and Interpretation, Book 4, 2002, 323-352.

4. IPCC. Climate change impacts adaptation and vulnerability, working group II contribution to the intergovernmental panel on climate change fourth assessment report, Summery for Policy Makers, Cambridge University Press, Cambridge, UK, 2007, 23.

5. Kalnay E, Cai M. Impact of urbanization and land-use change on climate. Nature 2003; 423:528-531.

6. Kendall MG. Rank Correlation Methods. Charles Griffin, London, 1975. 
7. Mann HB. Nonparametric tests against trend. Econometrica. 1945; 13:245-259.

8. Sen PK. Estimation of regression coefficient based on Kendall's tau. Journal of American Statistical Association. 1968; 63:1379-1389.

9. Salmi T, Maatta A, Anttila P, Airola TR, Amnell T. Detecting trends of annual values of atmospheric pollutants by the Mann-Kendall test and Sen's slope estimates -the Excel template application MAKESENS. Finnish Meteorological Institute Air Quality Research, 2002, (1-35).

10. Upadhye SK, Taley SM, Karunakar AP, Jadhav KA. Trends in rainfall and rainy days of Akola in Vidarbha Region. $3^{\text {rd }}$ National Conferenceon Water, Environment and Society 6- 8 June, Hyderabad, India. 2016, 342-347. 